ORIGINAL ARTICLE / ARTIGO ORIGINAL

\title{
What is the benefit of the biomedical and behavioral interventions in preventing HIV transmission?
}

\author{
Qual é o beneficio das intervenções biomédicas e \\ comportamentais na prevenção da transmissão do HIV?
}

Ricardo Kuchenbecker'

\begin{abstract}
Introduction: Scientific evidence supports the sinergy between biomedical and behavioral interventions aimed at preventing the transmission of HIV as a strategy to eradicate AIDS. Objective: To characterize comparatively the benefits from biomedical and behavioral interventions to prevent HIV transmission. Methods: Narrative review. We performed a comparative analysis of the benefits of studied interventions by means of estimating the number needed to treat (NNT). Evaluated interventions: counseling activities for behavior change to prevent exposure to HIV; antiretroviral pre-exposure prophylaxis (PrEP) and antiretroviral post-exposure prophylasis (PEP) for HIV and treatment of serodiscordant couples as a strategy for prevention of HIV transmission (TasP). Results: counseling interventions and TasP have smaller NNTs, equal to, respectively, $11(95 \% \mathrm{CI} 9-18)$ at 12 months and $34(95 \% \mathrm{CI} 23-54)$ in 42 months comparatively to PrEP interventions, that resulted in $41(95 \%$ CI $28-67)$ individuals receiving antiretrovirals in order to prevent one case of HIV infection at 36 months for men and serodiscordant couples. PEP interventions are associated with protective effects estimated at $81 \%$. Lack of trials evaluating PEP prevents estimate of NNT. Conclusion: The estimate of the NNT can be a helpful parameter in the comparison between the effectiveness of different behavioral and biomedical HIV prevention strategies. Studies evaluating the benefit and safety of combined behavioral and biomedical interventions are needed, especially considering the attributable fraction of each component. Integration of behavioral and biomedical interventions is required to achieve complete suppression of the virus, and thus reducing viral replication, infectivity and the number of cases.
\end{abstract}

Keywords: Anti-retroviral agents. Acquired immunodeficiency syndrome. HIV. Sexually transmitted diseases. Pre-exposure prophylaxis. Post-exposure prophylaxis. Circumcision, male. Therapeutics. Behavior. Disease prevention.

'Graduate Program in Epidemiology, School of Medicine, Hospital de Clínicas de Porto Alegre, Universidade Federal do Rio Grande do Sul - Porto Alegre (RS), Brazil.

Corresponding author: Ricardo Kuchenbecker. Hospital de Clínicas de Porto Alegre, Rua Ramiro Barcelos, 2.350, CEP: 90035-903, Porto Alegre, RS, Brasil. E-mail: rsk@hcpa.edu.br

Conflict of interests: nothing to declare - Financial support: none. 
RESUMO: Introdução: Evidências científicas sustentam a integração entre intervenções biomédicas e comportamentais visando à prevenção da transmissão do HIV como estratégia de erradicação da epidemia de AIDS. Objetivo: Caracterizar o benefício comparado de intervenções biomédicas e comportamentais na prevenção da transmissão do HIV. Métodos: Revisão narrativa. Análise comparativa dos benefícios das intervenções mediante estimativa do número necessário para tratamento (NNT). Intervenções avaliadas: aconselhamento para mudança de comportamentos relacionados à exposição ao HIV; profilaxia antirretroviral pré (PrEP) e pós-exposição (PEP) ao HIV; tratamento de casais sorodiscordantes como prevenção da transmissão do vírus (TcP). Resultados: Estratégias de aconselhamento e de TcP apresentam NNT menores, iguais a, respectivamente, 11 (IC95\% 9 - 18), em 12 meses, e 34 (IC95\% 23 - 54), em 42 meses, do que intervenções de PrEP, equivalentes a 41 (IC95\% 28 - 67) indivíduos para evitar um caso de infecção pelo HIV em 36 meses para homens e casais sorodiscordantes. Intervenções de PEP estão associadas a efeito protetor estimado em $81 \%$. Ausência de ensaios clínicos avaliando PEP impede a estimativa de NNT. Conclusão: A estimativa do NNT pode ser parâmetro útil de comparação da efetividade de diferentes estratégias comportamentais e biomédicas de prevenção da transmissão do HIV. Estudos avaliando o benefício e a segurança de intervenções comportamentais e biomédicas combinadas são necessários, sobretudo considerando a fração atribuível de cada componente. A integração entre intervenções comportamentais e biomédicas é necessária para que a supressão completa do vírus se torne possível, reduzindo a replicação viral, a infectividade e, consequentemente, o número de casos.

Palavras-chave: Antirretroviral. AIDS. HIV. Doença sexualmente transmissível. Profilaxia pré-exposição. Profilaxia pós-exposição. Circuncisão masculina. Tratamento. Comportamento. Prevenção.

\section{INTRODUCTION}

From the emergence of more powerful and better accepted treatment regimens for HIV infection, added to the increase in the number of individuals treated, there was a substantial reduction in morbidity and mortality associated with AIDS. This reduction is estimated at 4 million deaths among people living with HIV/AIDS (PLWHA) undergoing treatment ${ }^{1}$. International clinical recommendations and guidelines support the integration between biomedical and behavioral interventions aimed at preventing the transmission of $\mathrm{HIV}^{2,3}$. The Joint United Nations Programme on HIV / AIDS (UNAIDS) set goals for the disease: by 2020, 90\% of the PLWHA should know about their diagnosis; $90 \%$ of all PLWHA should receive antiretroviral therapy; $90 \%$ of people undergoing treatment should achieve durable viral suppression, representing effective treatment. These targets include a purpose: mathematical models suggest that, if these goals are met, they will allow eradication of the AIDS epidemic by $2030^{2}$.

Behavioral interventions include effective knowledge, attitudes and practices in reducing sexual exposure, and are carried out through the use of anti-HIV drugs, prevention of sexually transmitted diseases (STDs) and adherence to treatment. They also include effective communication, reduced risk compensation, maintenance of adherence and teaching-learning opportunities linked to other health interventions ${ }^{4}$. Since biomedical interventions include 
those that require the use of medications or other technologies involving continuous self-administration in order to be effective ${ }^{5}$, as is the case of antiretroviral pre- and post-exposure prophylaxis, treatment strategies for HIV infection as a form of prevention of transmission, among others. The aim of this study was to review the published literature evaluating HIV transmission prevention strategies through behavioral and biomedical interventions.

\section{METHODOLOGY}

We conducted a narrative review study using the following databases: Scientific Electronic Library Online (SciELO), U.S. National Library of Medicine (PubMed) and the Cochrane Central Register of Controlled Trials. These were surveyed for studies evaluating the efficacy and safety of the following behavioral and biomedical interventions aimed at reducing the risk of STD/HIV transmission, including:

1. interventions based on counseling for behavioral changes involving exposure to STD/HIV;

2. antiretroviral post-exposure prophylaxis for HIV (PEP);

3. antiretroviral pre-exposure prophylaxis for HIV (PrEP);

4. antiretroviral treatment as a prevention strategy against HIV transmission (TasP).

These four thematic areas were prioritized within a broader scope of behavioral and biomedical interventions on the growing trend of integrating strategies for prevention and treatment of HIV as a way to control the AIDS epidemic. Not included in the scope of this study are structural measures, which include those that focus on the physical, social, cultural, political and economic, legal aspects and/or aspects of environmental policies that demonstrate efficacy in preventing HIV transmission ${ }^{6}$. Interventions based on the use of microbicides, vaccines or male circumcision were not included.

The articles were identified and included using a search strategy conducted between January and May 2015. The results of the studies were summarized and accompanied, whenever possible, by estimates of the number needed to treat (NNT), as well its 95\% confidence interval $(95 \% \mathrm{CI})$ in order to better characterize the benefit of the interventions studied. Whenever possible, the estimate of the $\mathrm{NNT}^{7}$ was used as a way to allow a comparative analysis of the benefit presumed by the various biomedical and behavioral interventions evaluated.

\section{RESULTS}

\section{COUNSELING AIMED AT CHANGING RISK BEHAVIORS TO STD/HIV INFECTION}

Clinical trials, systematic reviews and international clinical guidelines present contradictory evidence about the benefit of interventions based on counseling to the adoption of 
safe behaviors regarding exposure to $\mathrm{HIV}^{8-13}$. In the same way, there is controversy regarding the benefits of pre- and post- HIV testing counseling strategies ${ }^{9-12}$.

Sexual counseling interventions for the prevention of STD/HIV infection were evaluated by a systematic review conducted by the U.S. Preventive Services Task Force ${ }^{8}$. Interventions gathered theoretical principles of behavioral change and counseling techniques similar to those used in motivational interviewing, including cognitive-oriented strategies for action $^{8}$. They were characterized as: "low intensity", with duration inferior to 0.5 hours (according to the authors, a feasible duration in the context of primary care); "moderate intensity", with duration between 0.5 hours and 2 hours and can be performed in a longer session or 2-3 brief sessions; "high intensity", with over two hours of duration (according to the authors, requiring multiple sessions and trained health professionals who can be the reference for primary care teams). They involve counseling strategies carried out by e-mail, computer, video and face-to-face contact; they are practiced in the context of primary health care (PHC), including reproductive health clinics, STD care services and mental health services. Most studies (28/31) were conducted in the United States, with 15 interventions in PHC services and 8 in STD clinics, predominantly involving women and African American or Latin populations ${ }^{8}$. The study estimated there was a $62 \%$ reduction in the chance of contracting an STD/HIV in the 12 months follow-up after "high intensity" counseling among adolescents and 30\% among adults (Chart 1). "Low" and "moderate intensity" interventions showed no reduction in the chance of STD/HIV infection. "High intensity" interventions were associated with higher frequency of condom use, particularly within 6 months of follow-up. According to the study, 11 "high risk" adolescents $(95 \%$ CI 9 - 18) should receive "high intensity" interventions to prevent one case of STD/HIV, assuming a cumulative incidence of $15 \%$ in one year". In "high risk" adult populations, "high intensity" counseling would be necessary for 25 individuals $(95 \% \mathrm{CI}$ 17 - 59) to prevent one case of STD/HIV in a context with $15 \%$ of cumulative annual incidence of STD $/ \mathrm{HIV}^{8}$. These data are limited primarily to the populations studied: African-American and Latino women and adolescents living in urban areas. The study did not consider other relevant risk reduction strategies for STD/HIV infection in addition to counseling initiatives, for example, partner notification, health and prevention programs in schools, condom distribution and counseling linked to HIV testing ${ }^{8}$.

The findings of the U.S. Preventive Services Task Force were corroborated by another systematic review evaluating behavioral interventions consisting of single one-hour sessions for the prevention of STD / HIV ${ }^{13}$. The study identified 20 studies $(\mathrm{n}=52,465)$ in which the recipients of behavioral interventions with one hour duration showed 35\% lower risk of STD/HIV, compared with groups that received the usual care or did not receive interventions: OR $0.65(95 \% \mathrm{CI} 0.55-0.77)^{13}$. According to the study, brief counseling interventions, with up to one hour in duration, can be used to maximize the benefits of biomedical technologies as prevention of HIV transmission ${ }^{13}$.

The effectiveness of voluntary counseling services and testing for HIV as a strategy for changing behavior related to exposure to HIV in low and middle income countries was analyzed 
Chart 1. Behavioral interventions for prevention of STD/HIV transmission.

\section{Objective}

Population studied

Intervention

Measure of association and impact $\mathrm{RR}, \mathrm{OR}, \mathrm{ARR}$ and NNT $(95 \% \mathrm{Cl})$

U.S. Preventive Services Task Force. Behavioral counseling for sexual risk reduction aimed at preventing STD/HIV in primary care in $2014^{8}$.

\begin{tabular}{|c|c|c|c|}
\hline $\begin{array}{l}\text { To assess the } \\
\text { benefits and risks of } \\
\text { sexual counseling } \\
\text { strategies in order } \\
\text { to reduce risk for } \\
\text { STIs/HIV infection }\end{array}$ & $\begin{array}{c}\text { Systematic review } \\
\text { of } 31 \text { RCTs } \\
\text { ( } n=70,324) \\
\text { comprising } \\
\text { predominantly } \\
\text { African-American } \\
\text { female adolescents } \\
\text { and adults, in } \\
\text { primary care } \\
\text { clinics and STD/HIV } \\
\text { services }\end{array}$ & $\begin{array}{l}\text { "Low intensity" interventions } \\
\text { Up to } 0.5 \text { hour of duration } \\
\text { "Moderate intensity" interventions } \\
\text { Between } 0.5 \text { and } 2 \text { hours of duration } \\
\text { "High intensity" interventions" } \\
\text { Over } 2 \text { hours of duration }\end{array}$ & $\begin{array}{l}\text { STD/HIV infections in adolescents in } 12 \text { months: } \\
\text { "Low" and “medium intensity" interventions } \\
\text { No difference between groups } \\
\text { "High intensity" interventions } \\
\text { OR }=0.38(95 \% \mathrm{Cl} 0.24-0.60) \\
\text { NNT = } 11(95 \% \mathrm{Cl} 9-18) \text { with cumulative incidence } \\
\text { of } 15 \% \text { per year. } \\
\text { STD/HIV infections in adults in } 12 \text { months: } \\
\text { "Low intensity" interventions } \\
\text { OR = } 0.85(95 \% \mathrm{Cl} 0.66-1.10) \\
\text { "Medium intensity" interventions } \\
\text { OR = } 0.88(95 \% \mathrm{Cl} 0.66-1.04) \\
\text { "High intensity" interventions } \\
\text { OR = } 0.70(95 \% \mathrm{Cl} 0.56-0.87) \\
\text { NNT = } 25(95 \% \mathrm{Cl} 1759), \text { with cumulative incidence } \\
\text { of } 15 \% \text { per year. }\end{array}$ \\
\hline \multicolumn{4}{|c|}{ Eaton L et al. Meta-analysis of behavioral interventions in single counseling sessions for STD/HIV prevention in $2012^{13}$. } \\
\hline $\begin{array}{l}\text { To assess whether } \\
\text { interventions for } \\
\text { risk reduction } \\
\text { of exposure to } \\
\text { HIV and other } \\
\text { STDs based on } \\
\text { single educational } \\
\text { sessions reduce } \\
\text { the occurrence of } \\
\text { STD/HIV }\end{array}$ & $\begin{array}{l}52,465 \text { people } \\
\text { in } 20 \text { RCTs and } \\
\text { observational } \\
\text { studies }\end{array}$ & $\begin{array}{l}\text { Behavioral strategies to reduce } \\
\text { incidence of STD/HIV from a } \\
\text { single counseling session aimed } \\
\text { at reducing behaviors related to } \\
\text { HIV exposure. Did not included } \\
\text { interventions involving counseling } \\
\text { and HIV testing }\end{array}$ & $\begin{array}{c}\text { STD/HIV occurrence } \\
\mathrm{OR}=0.65(95 \% \mathrm{Cl} 0.55-0.77) \\
\text { Condom use } \\
\mathrm{OR}=0.22(95 \% \mathrm{Cl} 0.06-0.37)\end{array}$ \\
\hline
\end{tabular}


Chart 1. Continuation.

\section{Objective}

Fonner et al. Systematic review on voluntary counseling and testing for changing HIV-related risk in developing countries ${ }^{14}$.

Systematically review the literature

examining the

effectiveness

of testing and

voluntary

counseling

strategies in

changing HIV-

related behaviors

in developing

countries

\section{0,309 individuals evaluated in one RCT and several observational studies}

Systematic review and meta-analysis involving studies conducted in low and middle income countries: SubSaharan Africa, Zimbabwe, Uganda, Zambia, Mozambique and Kenya

\section{Reduction in number of sexual partners $\mathrm{OR}=0.69(95 \% \mathrm{Cl} 0.53-0.90)$ \\ Increased frequency of condom use $\mathrm{OR}=1.39(95 \% \mathrm{Cl} 0.97-1.99)$ \\ Increased frequency of condom use among HIV-positive individuals $\mathrm{OR}=3.24(95 \% \mathrm{Cl} 2.29-4.58)$}

There were no differences in the incidence of HIV and STD/HIV between participants who received voluntary counseling associated with HIV testing and those who did not receive such strategy

Study: effectiveness of counseling for risk reduction in transmission of HIV and STDs. RESPECT Study, $1998^{9}$.

\begin{tabular}{l|r|} 
& \\
To compare & \\
the effects of & \\
two interactive & \\
counseling & \\
interventions for & \\
STD/HIV prevention & individuals \\
with educational & \\
messages & \\
& \\
& \\
&
\end{tabular}

\section{Group 1:}

Extended counseling +4 interactive sessions at $3-4$ week intervals $(200$

$$
\text { minutes total) }
$$

$$
\text { Group 2: }
$$

Brief counseling +2 interactive sessions at $7-10$ day intervals ( 40 minutes total)

$$
\text { Group 3: }
$$

Two educational messages given at $7-10$ days

$$
\text { Group 4: }
$$

Two educational messages at $7-10$ days without follow-up by the end of the study
STD/HIV infections in 6 months: Extended counseling (group 1)

$\mathrm{RR}=0.69(95 \% \mathrm{Cl} 0.54-0.88)$

NNT $=32(95 \% \mathrm{Cl} 19-91)$

Brief counseling (group 2)

$\mathrm{RR}=0.72(95 \% \mathrm{Cl} 0.56-0.91)$

NNT $=35(95 \% \mathrm{Cl} 20-116)$

STD/HIV infections in 12 months:

Extended counseling (group 1)

$\mathrm{RR}=0.78(95 \% \mathrm{Cl} 0.65-0.95)$

NNT $=32(95 \% \mathrm{Cl} 18-146)$

Brief counseling (group 2)

$\mathrm{RR}=0.79(95 \% \mathrm{Cl} 0.68-0.98)$

$\mathrm{NNT}=38(95 \% \mathrm{Cl} 19-527)$ 
Chart 1. Continuation.

\begin{tabular}{|c|c|c|c|}
\hline Objective & Population studied & Intervention & $\begin{array}{c}\text { Measure of association and impact } \\
(\mathrm{RR}, \mathrm{OR} \text { and NNT }(95 \% \mathrm{Cl}))\end{array}$ \\
\hline \multicolumn{4}{|c|}{ Relative effectiveness of counseling for HIV prevention with rapid and conventional tests. Randomized clinical trial. RESPECT 2 Study, $2005^{10}$. } \\
\hline $\begin{array}{l}\text { To compare the } \\
\text { effectiveness of } \\
\text { counseling and } \\
\text { testing using } \\
\text { rapid HIV testing, } \\
\text { in a single visit, } \\
\text { with counseling } \\
\text { and testing with } \\
\text { standard test, } \\
\text { conducted in } \\
\text { two visits }\end{array}$ & $\begin{array}{l}3,281 \text { seronegative } \\
\text { individuals }\end{array}$ & $\begin{array}{c}\text { Standard counseling: } \\
\text { One 40-minute session + } \\
\text { conventional HIV test (two visits) } \\
\text { Brief counseling: } \\
\text { One 30-minute session + rapid HIV } \\
\text { test (one visit) }\end{array}$ & $\begin{array}{c}\text { STD/HIV infections in } 12 \text { months: } \\
\text { Brief counseling (group } 2) \\
\text { RR }=1.1(95 \% \mathrm{Cl} 0.96-1.29) \\
\text { STD/HIV infections in } 12 \text { months among men who have } \\
\text { sex with men: } \\
\text { Brief counseling (group } 2) \\
\text { RR }=1.86(95 \% \mathrm{Cl} 0.92-3.76) \\
\text { STD/HIV infections in individuals without STD/HIV history: } \\
\text { Brief counseling } \\
\text { RR }=1.21(95 \% \mathrm{Cl} 0.99-1.48)\end{array}$ \\
\hline \multicolumn{4}{|c|}{ Effect of counseling with rapid testing in reducing the risk of STD/HIV infection. AWARE Study, $2013^{11}$. } \\
\hline $\begin{array}{l}\text { To evaluate the } \\
\text { effect of brief } \\
\text { counseling } \\
\text { strategies centered } \\
\text { on the patient at the } \\
\text { moment of rapid } \\
\text { HIV testing on the } \\
\text { risk of subsequent } \\
\text { STD/HIV infection }\end{array}$ & $\begin{array}{c}\text { 5,012 patients from } \\
\text { nine American DST } \\
\text { clinics }\end{array}$ & $\begin{array}{l}\text { Counseling group: } \\
\text { Risk reduction strategies based on } \\
\text { the patient, recommendations used } \\
\text { in the RESPECT } 2 \text { Study, followed } \\
\text { by rapid testing } \\
\text { Control group: } \\
\text { Rapid test accompanied by verbal } \\
\text { information corresponding to } \\
\text { the test procedure itself, its } \\
\text { interpretation and information } \\
\text { about the test's "window" period }\end{array}$ & $\begin{array}{c}\text { STD/HIV infections in } 6 \text { months: } \\
\text { ARR }=1.12(95 \% \mathrm{Cl} 0.94-1.33) \\
\text { STD/HIV infections in six months among MSM: } \\
\text { ARR }=1.41(95 \% \mathrm{Cl} 1.05-1.90) \\
\text { STD/HIV infections in six months among women: } \\
\text { ARR }=1.07(95 \% \mathrm{Cl} 0.79-1.43) \\
\text { STD/HIV infections in six months among MSW: } \\
\text { ARR }=0.81(95 \% \mathrm{Cl} 0.50-1.31)\end{array}$ \\
\hline
\end{tabular}

RR: Relativ risk; OR: odds ratio; RRA: adjusted risk ratio; NNT: Number Needed to Treat. 
in another systematic review ${ }^{14}$. Among the 17 studies identified, 8 provided data for meta-analysis, corresponding to subjects receiving counseling related to HIV testing, who showed a $31 \%$ lower frequency of "reporting a high number of sexual partners", compared to those who did not receive counseling: OR 0,69 (95\%CI $0.53-0.90)$. Benefits related to greater adherence to the use of condoms during sexual intercourse were not demonstrated ${ }^{14}$. The study found no significant differences in the incidence of STD/HIV among patients who received voluntary counseling pre- and post-test. Among the behaviors associated with increased risk, condom use showed significant changes only in the group with positive results for HIV. According to the study, counseling related to testing reduces risk behaviors related to HIV by significantly reducing the number of sexual partners and increasing the chance of condom use and of engaging in protected sexual activity, compared to those PLHIV who did not receive counseling. The great diversity of contexts in which the studies were conducted and their different designs can compromise the external validity of their findings. There were clinical trials, observational studies, "before-and-after" studies, cohort and cross-sectional studies, with consequent heterogeneity in the follow-up times of the research subjects ${ }^{14}$.

Among the largest randomized controlled trials (RCTs) that evaluated counseling strategies associated with HIV testing, three stand out: the RESPECT (1998) ${ }^{9}$, RESPECT 2 $(2005)^{10}$ and AWARE $(2013)^{11}$ studies, whether due to the number of subjects involved or the interventions being evaluated, all performed in the United States. These RCTs have shown conflicting results regarding the benefit of counseling linked to HIV testing (Chart 1).

In the RESPECT Study ${ }^{9}$, patients enrolled for counseling sessions related to HIV testing showed lower frequency of STD/HIV in 12 months and higher frequency of condom use, compared to those who received only "educational messages". The NNTs estimated by the study for individuals undergoing counseling for STD/HIV prevention ranged from 32 (95\%CI 19 - 91) (extended counseling) and 38 (95\%CI 19 - 527) (brief counseling). In the RESPECT Study, men who have sex with men (MSM) were not included and there was no rapid HIV test available 9

In the RESPECT 2 Study, subjects were randomized to receive counseling and rapid HIV testing in a single consultation or testing with standard anti-HIV test performed on two visits. The cumulative incidence of STD/HIV in 12 months was higher in the group undergoing the rapid test compared to the control group, although not statistically significant: RR $1.11(95 \% \mathrm{CI}$ $0.96-1.29 ; \mathrm{p}=0.15)$. There were no differences in the incidence of STD/HIV between the two groups ${ }^{10}$. RESPECT 2 included MSM. The short-term findings (six months) of this study suggest that the interventions based on the rapid test showed lower effectiveness in relation to STI/HIV compared to the standard counseling, especially among MSM, a finding that was not corroborated by the results in 12 months, when there was no difference between groups ${ }^{10}$.

The AWARE Study evaluated the effect of brief counseling strategies on the occasion of the rapid HIV test, compared to information supplied solely for the test itself ${ }^{11}$. The study found no difference in the cumulative incidence of STD/HIV in six months of follow-up ${ }^{11}$. There was a higher risk of STD/HIV infection among MSM in six months of follow-up: adjusted hazard ratio: 1.41 (95\%CI $1.05-1.90)$. 


\section{ANTIRETROVIRAL POST-EXPOSURE PROPHYLAXIS}

HIV post-exposure prophylaxis (PEP) is based on the "window of opportunity" represented by the time between the entry of the virus in the body after exposure and its arrival to the regional lymph nodes, a period that can last up to 72 hours. Experimental models suggest that this is the deadline for the effective use of antiretrovirals as a strategy for reduction of viral inoculum, with the first two hours being the best time for carrying out this strategy ${ }^{15}$.

Different PEP strategies are supported from the extrapolation of the benefit of using antiretrovirals to prevent mother-to-child transmission of HIV, as in Study ACTG 076, which demonstrated a $25 \%$ reduction in transmission of the virus in placebo-treated cases to below $1 \%$ in the group receiving the intervention with zidovudine during prenatal care and labor, and, for the baby, in the first four weeks after birth ${ }^{16}$.

The risk of HIV infection after occupational exposure was estimated in a study of cases and controls involving health professionals who have experienced needlestick injuries involving blood infected with the virus ${ }^{17}$. There is greater risk of infection if the source patient's blood has high plasma count, if the volume exposed is great and if there is exposure related to a deep wound, such as needlestick accident situations determined by syringes and other instruments for surgical use ${ }^{17}$. Similarly, receptive anal sex, compared to insertive sex and the shared use of syringes among injectable drug users, account for situations of higher virus transmission risk.

PEP strategies have been used in situations involving individuals who have has sexual activity without condom use, among injectable drug users who shared needles and also other sources of exposure, such as occupational exposure ${ }^{18}$. Such situations include a risk of transmission that is difficult to quantify. Other determinants of HIV transmission risk include viral load, mucosal integrity, the presence of trauma, such as in situations of sexual violence, among others.

A systematic review and meta-analysis evaluating the efficacy of PEP studies in nonhuman primate models ${ }^{15}$ provided scientific evidence to the recommendations of the World Health Organization (WHO) on the subject ${ }^{19}$, given the ethical limitations in conducting human studies beyond the observational studies ${ }^{17}$. The review identified 28 studies evaluating different PEP strategies in primates, with an $89 \%$ lower risk of seroconversion among those who received PEP, compared to those who did not: OR $0.11(95 \% \text { CI } 0.05-0.23)^{15}$. It is the measure of close association to that estimated by the best evidence produced in humans: case studies and controls involving health workers exposed to needlestick injuries with blood infected with HIV: OR $=0.19(95 \% \text { CI } 0.06-0.52)^{17}$ (Chart 2).

Different strategies of combined use of antiretrovirals have been used as PEP ${ }^{19-23}$. Beyond the scope of this article is the characterization of different combinations of drugs used as PEP. Despite the rationalization of PEP as a strategy to prevent HIV infection, various studies point to their low usage rate. Several factors determine the complexity of the offer of PEP: no prior knowledge of the benefits and easier access to services; lack of adequate risk perception, hindering the decision to seek the PEP in a timely manner; 
inadequate adhesion due to adverse events and risk compensation behavior ${ }^{24}$. These factors, added to the existing barriers to timely access to health services and the need for counseling, HIV testing and strategies to reduce the risk of exposure to the virus, help to reduce the benefits of $\mathrm{PEP}^{18}$.

In a Brazilian cohort with MSM $(\mathrm{n}=200)$ with sexual practices involving unprotected exposure to HIV presented 11 cases of infection in 24 months of follow-up, 10 of which have been identified by researchers as related to inadequate risk assessments on the part of those involved, resulting in the non-utilization of PEP. Even with easy access to the drugs necessary for PEP, individuals who became infected seem to have underestimated the risk of infection ${ }^{25}$. Factors that contribute to the benefit of PEP strategies not reaching its potential needs to be better understood before the emergence of PrEP strategies ${ }^{26-28}$. This is due to the behaviors associated with risk of exposure, the need for counseling and testing interventions, the high dropout rate due to adverse events and existing barriers to access to drugs in health services. These represent missed opportunities in which subjects using the PEP may be potential candidates to benefit from $\operatorname{PrEP}^{27}$.

\section{ANTIRETROVIRAL PRE-EXPOSURE PROPHYLAXIS}

The prophylactic use of antiretrovirals to prevent sexual transmission of HIV (PrEP), either through medication used topically or orally, has been evaluated in different RCTs ${ }^{29-35}$. PrEP comprises the use of one or more antiretroviral drugs in seronegative individuals, aimed at preventing the infection through contact with the virus through sex or sharing of needles among injectable drug users.

A systematic review evaluated the benefit of PrEP in preventing HIV transmission ${ }^{36}$. The study identified seven RCTs ${ }^{29-35}$, all using tenofovir alone or in combination with emtricitabine (Chart 2). In addition to antiretroviral drugs, patients received combined counseling strategies in pre- and post-testing moments, exposure prevention interventions, condoms and treatment of STDs ${ }^{29-35}$. The review found a $47 \%$ reduction in the risk of HIV acquisition: RR $0.53(95 \% \text { CI } 0.40-0.71)^{36}$.

In the Partners PrEP Study ${ }^{29}$, heterosexual men and women in serodiscordant couples were randomized to receive tenofovir or tenofovir and emtricitabine daily versus placebo. The groups receiving the two PrEP schemes showed a decrease in the risk of HIV infection, resulting in NNT values between those treated to avoid one case of infection corresponding to $46(95 \%$ CI $30-83)$ for the tenofovir group and $41(95 \%$ CI $28-67)$ for the tenofovir plus emtricitabine group, compared to the placebo ${ }^{29}$. In the TDF2 Study ${ }^{33}$, heterosexual women and men were administered tenofovir plus emtricitabine daily versus placebo. The group that received the PrEP showed a 78\% of protection against the risk of HIV infection, resulting in an NNT of 41 (95\%CI $22-154)$ individuals using PrEP to prevent one case of infection by the virus. In the iPrEX Study ${ }^{31}$, transgender men and women (transvestites) who have sex with men used tenofovir plus emtricitabine versus 
Chart 2. Biomedical interventions aimed at preventing HIV infection.

\begin{tabular}{|l|c|c|c|c|c|c} 
Objective & $\begin{array}{c}\text { Population } \\
\text { studied }\end{array}$ & Intervention & $\begin{array}{c}\text { Relative } \\
\text { reduction } \\
\text { of incidence } \\
(95 \% \mathrm{Cl})\end{array}$ & $\begin{array}{c}\text { Blood detection } \\
\text { of prophylaxis } \\
\text { among } \\
\text { seroconverted } \\
\text { patients }\end{array}$ & $\begin{array}{c}\text { Protective factor (\%) and } \\
\text { safety }\end{array}$ & NNT (95\%Cl) \\
\hline \multicolumn{2}{|c|}{ Sexual post-exposure prophylaxis (PEP). }
\end{tabular}

Cardo D et al. Case and control studies on seroconversion among healthcare workers after percutaneous exposure, $1997^{17}$.

\begin{tabular}{|c|c|c|c|c|c|c|}
\hline $\begin{array}{l}\text { To identify risk factors for HIV } \\
\text { transmission in health care } \\
\text { workers after percutaneous } \\
\text { exposure to blood infected with } \\
\text { the virus }\end{array}$ & $\begin{array}{l}\text { Health } \\
\text { professionals: } 33 \\
\text { cases and } 665 \\
\text { controls }\end{array}$ & - & $\begin{array}{c}\mathrm{OR}=0.19(95 \% \mathrm{Cl} \\
0.06-0.52)\end{array}$ & - & $81 \%$ & - \\
\hline \multicolumn{7}{|c|}{ Irvine C et al. Systematic review on the effectiveness of PEP in studies with animal models (primates) ${ }^{15}$. } \\
\hline $\begin{array}{l}\text { To evaluate the efficacy of PEP } \\
\text { in animal models (primates) }\end{array}$ & $\begin{array}{c}\text { Primates } \\
\text { ( } n=28 \text { studies, } \\
408 \text { primates) }\end{array}$ & $\begin{array}{l}\text { Different PEP } \\
\text { strategies } \\
\text { involving } \\
\text { multiple } \\
\text { ARVs\& }\end{array}$ & $\begin{array}{c}\mathrm{OR}=0.11(95 \% \mathrm{Cl} \\
0.05-0.23)\end{array}$ & - & $89 \%$ & - \\
\hline \multicolumn{7}{|l|}{ Partners PrEP Study, $2012^{29}}$. \\
\hline $\begin{array}{l}\text { To evaluate the efficacy } \\
\text { and safety of TDF or TDF/ } \\
\text { FTC versus placebo as a } \\
\text { strategy for prevention of } \\
\text { HIV-1 infection among HIV-1 } \\
\text { serodiscordant men and } \\
\text { women couples }\end{array}$ & $\begin{array}{c}4,747 \\
\text { heterosexual } \\
\text { men and women } \\
\text { with known } \\
\text { seropositive } \\
\text { partner } \\
\text { (serodiscordant } \\
\text { couples) }\end{array}$ & $\begin{array}{l}\text { Daily oral } \\
\text { intake of TDF } \\
\text { versus daily } \\
\text { oral intake } \\
\text { of TDF/ } \\
\text { FTC versus } \\
\text { placebo }\end{array}$ & $\begin{array}{c}\text { TDF: } 67 \% \\
(95 \% \mathrm{Cl} 44-81) \\
\text { TDF/FTC: } 75 \% \\
(95 \% \mathrm{Cl} 55-87)\end{array}$ & $81 \%$ & $\begin{array}{c}86 \% \text { (TDF), 90\% (TDF/FTC) } \\
\text { in patients with detectable } \\
\text { TDF } \\
\text { No major EAD differences }\end{array}$ & $\begin{array}{c}\text { Daily TDF: } \\
\text { NNT }=46 \\
(95 \% \mathrm{Cl} 30-83) \\
\text { TDF/FTC: } \\
\text { NNT }=41 \\
(95 \% \mathrm{Cl} 28-67) \\
\text { in } 36 \text { months }\end{array}$ \\
\hline \multicolumn{7}{|l|}{ TDF2 Study, $2012^{33}$} \\
\hline $\begin{array}{l}\text { To evaluate the efficacy and } \\
\text { safety of TDF/FTC versus } \\
\text { placebo in preventing HIV } \\
\text { infection among sexually } \\
\text { active heterosexual adults }\end{array}$ & $\begin{array}{c}1,219 \\
\text { heterosexual } \\
\text { men and women }\end{array}$ & $\begin{array}{l}\text { Daily oral } \\
\text { intake of TDF/ } \\
\text { FTC versus } \\
\text { placebo }\end{array}$ & $\begin{array}{l}\text { TDF/FTC: } 63 \% \\
(95 \% \mathrm{Cl} 22-83)\end{array}$ & $79 \%$ & $\begin{array}{c}78 \% \\
\text { TDF/FTC } \\
\text { higher frequency of nausea, } \\
\text { vomiting and dizziness }\end{array}$ & $\begin{array}{c}\mathrm{NNT}=41 \\
(95 \% \mathrm{Cl} 22-154) \\
\text { in } 1.1 \text { years }\end{array}$ \\
\hline
\end{tabular}


Chart 2. Continuation.

\begin{tabular}{|c|c|c|c|c|c|c|}
\hline Objective & $\begin{array}{l}\text { Population } \\
\text { studied }\end{array}$ & Intervention & $\begin{array}{l}\text { Relative } \\
\text { reduction } \\
\text { of incidence } \\
(95 \% \mathrm{Cl})\end{array}$ & $\begin{array}{c}\text { Blood detection } \\
\text { of prophylaxis } \\
\text { among } \\
\text { seroconverted } \\
\text { patients }\end{array}$ & $\begin{array}{l}\text { Protective factor (\%) and } \\
\text { safety }\end{array}$ & NNT $(95 \% \mathrm{Cl})$ \\
\hline \multicolumn{7}{|l|}{ iPrEX Study, $2010^{31}$} \\
\hline $\begin{array}{l}\text { To evaluate the efficacy and } \\
\text { safety of the daily oral intake of } \\
\text { TDF/FTC compared to placebo in } \\
\text { preventing HIV infection among } \\
\text { men and transgender women } \\
\text { who have sex with men }\end{array}$ & $\begin{array}{l}\text { 2,499 MSM and } \\
\text { transvestites }\end{array}$ & $\begin{array}{l}\text { Daily oral } \\
\text { intake of TDF/ } \\
\text { FTC versus } \\
\text { placebo }\end{array}$ & $\begin{array}{l}\text { TDF/FTC: } 44 \% \\
(95 \% \mathrm{Cl} 15-63)\end{array}$ & $51 \%$ & $\begin{array}{l}\text { 92\% in participants with } \\
\text { detectable TDF or FTC; } 99 \% \\
\text { with TDF concentrations with } \\
\text { daily use }\end{array}$ & $\begin{array}{c}\text { NNT } 45 \\
(95 \% \mathrm{Cl} 26-140) \\
\text { in } 1.8 \text { years }\end{array}$ \\
\hline \multicolumn{7}{|l|}{ FEM-PrEP Study, $2012^{34}$} \\
\hline $\begin{array}{l}\text { To evaluate the efficacy and } \\
\text { safety of the daily oral intake } \\
\text { of TDF/FTC compared to } \\
\text { placebo in preventing HIV } \\
\text { infection among women }\end{array}$ & 2,120 women & $\begin{array}{l}\text { Daily oral } \\
\text { intake of TDF/ } \\
\text { FTC versus } \\
\text { placebo }\end{array}$ & $\begin{array}{c}\text { TDF/FTC } \\
6 \%(95 \% \mathrm{Cl} \\
52-41) . \mathrm{No} \\
\text { statistically } \\
\text { significant } \\
\text { reduction in } \\
\text { HIV incidence }\end{array}$ & $\begin{array}{l}35 \text { to } 38 \% \text { in a } \\
\text { single visit }\end{array}$ & $\begin{array}{l}\text { Very low frequency in } \\
\text { PrEP use. TDF/FTC group } \\
\text { reported nausea and } \\
\text { vomiting rates and higher } \\
\text { liver transaminases than } \\
\text { the control group }\end{array}$ & Study interrupted \\
\hline \multicolumn{7}{|l|}{ Bangkok TDF Study, $2013^{35}$. } \\
\hline $\begin{array}{l}\text { To evaluate the efficacy and } \\
\text { safety of the daily oral intake } \\
\text { of TDF versus placebo in } \\
\text { preventing HIV infection } \\
\text { among injectable drug users }\end{array}$ & 2,413 IDU & $\begin{array}{l}\text { TDF versus } \\
\text { placebo }\end{array}$ & $\begin{array}{c}\text { TDF 48.9\% } \\
(95 \% \mathrm{Cl} 9.6 \\
-72.2)\end{array}$ & NA & $\begin{array}{l}\text { Nausea and vomiting more } \\
\text { frequent in the TDF Group. } \\
\text { Similar frequency of severe } \\
\text { EAD in both groups }\end{array}$ & \\
\hline
\end{tabular}

Study on the prevention of infection by HIV-1 with early antiretroviral therapy. HPTN052, $2011^{40}$.

\begin{tabular}{|c|c|c|c|c|c|c|}
\hline $\begin{array}{l}\text { To compare early-start with } \\
\text { late-start antiretroviral therapy } \\
\text { in HIV-infected patients in } \\
\text { stable sexual relationships } \\
\text { with seronegative partners }\end{array}$ & $\begin{array}{l}1,763 \\
\text { heterosexual } \\
\text { and homosexual } \\
\text { serodiscordant } \\
\text { couples }\end{array}$ & $\begin{array}{l}\text { Early-start } \\
\text { versus } \\
\text { late-start } \\
\text { antiretroviral } \\
\text { therapy }\end{array}$ & $\begin{array}{l}\text { HIV incidence: } \\
0.1 \% \text { per } 100 \\
\text { persons- } \\
\text { year versus } \\
1.7 \% \text { per } 100 \\
\text { persons-year. }\end{array}$ & - & $\begin{array}{c}96 \% \\
(95 \% \mathrm{Cl} 73-99)\end{array}$ & $\begin{array}{c}\text { NNT } 34(95 \% \mathrm{Cl} \\
23-54) \text { in } 42 \\
\text { months }\end{array}$ \\
\hline
\end{tabular}

RR: relativ risk; OR: odds ratio; RRA: adjusted risk ratio; NNT: Number Needed to Treat; ARV: antiretrovirals; TDF: tenofovir; FTC: emtricitabine. 
placebo, resulting in an NNT of 45 (95\%CI 26 - 140) using PrEP to prevent one case of infection. In the FEM-PrEP Study ${ }^{34}$, women were administered tenofovir plus emtricitabine versus placebo daily. The study was halted early by the absence of benefits ${ }^{34}$.

A placebo-controlled double-blind RCT evaluated the use of oral tenofovir as a strategy to prevent HIV infection among injectable drug users $(\mathrm{n}=2,413)$ in Thailand ${ }^{35}$. In the group receiving tenofovir daily, the incidence of HIV infection was 0.35 per 100 persons-year, compared to 0.68 per 100 persons-year, representing a reduction of $48.9 \%$ in the incidence of HIV infection $(95 \% \mathrm{CI} 9.6-72.2)$. There were no significant differences in the frequency of adverse events.

In all studies with PrEP, subjects received behavioral interventions including counseling sessions and access to condoms as part of HIV prevention strategies ${ }^{29-35}$. Although present, the fraction attributable to the protective effect of behavioral interventions is difficult to measure in the context of studies evaluating PrEP.

International guidelines support that biomedical interventions based on PrEP consist of "an option in HIV transmission prevention" among heterosexual men and women with active sex life, as well as MSM and injectable drug users with "substantial risk" of HIV acquisition".

Although the studies with PrEP do not have sufficient follow-up time for proper evaluation of the risks in inducing viral resistance to drugs and the emergence of risk compensation situations, preliminary evidence does not support such risks. An Australian cohort of MSM, PrEP users, showed no increase in risk compensation ${ }^{37}$, although they presented higher seroconversion rates compared to those who did not.

\section{TREATMENT OF HIV INFECTION AS A TRANSMISSION PREVENTION STRATEGY}

The highly potent antiretroviral therapy made it possible to reduce the sexual transmission of HIV to very low levels. In 2008, from the results presented by the Swiss HIV Cohort Study, health authorities of that country stated that PLHIV undergoing antiretroviral treatment with complete and continuous suppression of the plasma count for at least 6 months and without STD are no longer considered as potential sources of HIV transmission ${ }^{38}$.

A systematic review examined 11 groups ( $n=5,021$ heterosexual couples), assessing the risk of HIV transmission through unprotected sex due to viral load, as well as the antiretroviral treatment. There was no HIV transmission among couples in which the partner undergoing treatment had a viral load below 400 copies $/ \mathrm{mL}^{39}$. Results like these have supported the proposition of the concept of "treatment as prevention" (TasP), embodied by the findings of the HIV Prevention Trials Network 052 (HTPN 052) RCT ${ }^{40}$.

The HPTN 052 evaluated the antiretroviral treatment as a strategy for reducing the transmission of HIV among serodiscordant $\operatorname{couples}^{40}$ (Chart 2). Eligibility criteria included seropositive individuals without prior treatment and with CD4 counts between 350 and 550 cells $/ \mathrm{mm}^{3}$. Participant couples should be in a stable relationship for at least three 
months $s^{38,41}$. Serodiscordant couples were randomized so that the infected partner received "early" antiretroviral therapy, starting immediately at the time of enrollment in the study, or "late", initiated when CD4 lymphocyte counts reached values below 250 cells $/ \mathrm{mm}^{3}$ or after clinical manifestation that defined the onset of AIDS ${ }^{40}$. Individuals in the group that started early treatment had $96 \%$ less risk of virus transmission (HR 0.04 ; 95\%CI $0.01-0.26$ ) compared to those with a late start, corresponding to 28 transmissions of HIV, of which 27 occurred in late-start group ${ }^{40}$.

A systematic review evaluated the use of antiretroviral therapy in serodiscordant couples for HIV infection as a strategy for reducing transmission to the uninfected partner, compared to untreated serodiscordant couples ${ }^{42}$. The risk ratio of the other 9 observational studies identified in addition to the HPTN052 $2^{40}$ was $0.58(95 \% \mathrm{CI} 0.35-0.96)^{42}$. The study concluded that serodiscordant couples benefitted from the treatment in situations where the index partner presents counts of up to $550 \mathrm{CD} 4 / \mathrm{mm}^{3}$. It also pondered about uncertainties regarding the durability of the protection offered, the balance between the benefits and risks of early-start antiretroviral therapy, as well as the difficulties related to adherence in the long term and the risk of transmission of resistant strains ${ }^{42}$.

\section{DISCUSSION}

The comparative analysis of the benefit represented by the NNTs of different studies evaluating the behavioral and biomedical interventions aimed at reducing the risk of STD/ HIV transmission allows the identification of lower NNTs accompanied by closer confidence intervals for counseling ${ }^{8}$ and treatment strategies to prevent HIV transmission ${ }^{40}$. Interventions providing counseling sessions of over 2 hours presented NNTs between 11 $(95 \%$ CI $9-18)$ and $25(95 \%$ CI $17-59)$ in 12 months $^{8}$. On the other hand, TasP presented NNT equal to $34(95 \%$ CI $23-54)$ in 42 months $^{40}$. Moreover, interventions based on PrEP presented NNTs ranging between $41(95 \%$ CI $28-67)$ at 36 months, as in the Partners PrEP Study ${ }^{29}$, and $45(95 \% \mathrm{CI} 26-140)$ in 1.8 years, as in $\mathrm{PrEx}^{31}$. That is, considering the NNT as a benchmark between different behavioral and biomedical transmission prevention strategies discussed in this article, those represented by counseling and TasP require smaller numbers of patients and relatively less time to measure the expected benefits. Such differences may be important from the standpoint of public health strategies, although they do not serve as an isolated parameter for analysis.

It is worth considering that there is some controversy in the literature about the benefit of counseling interventions, particularly those related to HIV testing ${ }^{8-11,13,14}$. In addition, there are numerous other aspects to be considered, including the availability of resources needed to carry out interventions, the feasibility, acceptability, among others. These aspects can have a greater relevance than the parameter proposed by the NNT estimates of the analyzed interventions. Added to this is the fact that there is not enough evidence establishing the efficacy and safety of many behavioral and biomedical interventions, including those 
presented here. One must also be consider that biomedical interventions involving different PrEP and PEP strategies also imply initiatives for behavioral changes. Studies evaluating different PrEP and PEP interventions included counseling and behavioral change activities analyzed globally, and the contribution of each of the interventions to reduce the risk of exposure to STDs/HIV cannot be pointed out.

Lastly, it is important to state that interventions such as TasP include several implications:

a) individuals on antiretrovirals must maintain adherence to treatment, ensuring complete suppression of the virus and reducing viral replication;

b) there is a reduction in infectivity, building a close association between plasma viral load and the viral load present in genital secretions;

c) the concentration of HIV in the genital immune system remains relatively stable;

d) there is constancy in sexual behavior, resulting in safe behavior regarding HIV exposure;

e) individuals remain free of STDs ${ }^{4}$. To meet the goals established, TasP interventions still need other combined strategies, including universal access to voluntary testing for HIV, the adhesion of PLWHA to treatment services, counseling strategies and provision of condoms, treatment of STDs, among others ${ }^{5}$.

For their part, PrEP and PEP strategies cannot be understood merely as biomedical interventions. As STD prevention strategies - including HIV - they involve the combination of drug provision actions with counseling for risk reduction and adherence to the use of antiretrovirals ${ }^{27}$.

\section{CONCLUSIONS}

The 90/90/90 goals set by UNAIDS and endorsed by Brazil imply an integration of care and prevention practices through the adoption of behavioral and biomedical interventions combined. Increased access to HIV testing and treatment demand joint capacity from health services, to ensure that PLWHA maintain adherence to the treatment, achieving success for themselves, through undetectability of viral load as a result of effective therapy, and for others, through the reduction of the risk of transmission. The benefits of behavioral and biomedical interventions imply a link between the agendas of prevention, care and respect for the human rights of PLWHA from a comprehensiveness standpoint.

\section{REFERENCES}

1. World Health Organization. Global Uptade on HIV Treatment 2013 : Results, Impact and Opportunities. Global update on HIV treatment 2013: results, impact and opportunities. Geneva, Switzerland: World Health Organization; 2013. 7 p.

2. UNAIDS. Ambitious Treatment Targets: Writing the final chapter of the AIDS epidemic. Geneva; 2014.
3. Marrazzo J, Del Rio C, Holtgrave D, Cohen M, Kalichman S, Mayer, KH, Montaner J. HIV prevention in clinical care settings. 2014 recommendations of the International Antiviral Society - USA Panel. JAMA 2014; 390-409.

4. Kalichman S. HIV Treatments as prevention(TasP). New York: Springer; 2013. 132 p. 
5. Mayer K, Gazzard B, Zuniga J, Amico K, Anderson J, Azad Y, et al. Controlling the HIV epidemic with antiretrovirals: IAPAC consensus statement on treatment as prevention and preexposure prophylaxis. J Int Assoc Provid AIDS Care 2013; 12(3): 208-16.

6. Golden R, Collins C, Cunningham S, Newman E, CardJ. Best evidence structural interventions for HIV prevention. New York: Springer; 2013.

7. Guyatt G, Sackett D, Taylor W, ChongJ, Roberts R, Pugsley S. Determining optimal therapy. Randomized trials in individual patients. N Engl J Med 1986; 314(14): 889-92.

8. Connor EAO, Lin JS, Burda BU, Henderson JT, Walsh ES, Whitlock EP. Behavioral sexual risk-reduction counseling in primary care to prevent sexually transmitted infections : an updated systematic evidence review for the U.S. Preventive Services Task Force. Ann Intern Med 2014; doi: 10.7326/M14-0475.

9. Kamb M, Fishbein M, Douglas J, Rhodes F, Rogers J, Bolan G, et al. Efficacy of risk-reduction counseling to prevent human immunodeficiency virus and sexually transmitted diseases a randomized controlled trial. JAMA 1998;280(13):1161-7.

10. Metcalf C, Douglas J, Malotte C, Cross H, Dillon m B, Paul S. Relative efficacy of prevention counselling with rapid and standard HIV testing: a randomized, controlled trial (RESPECT-2). Sex Transm Dis 2005; 32(2): 130-8.

11. Metsch LR, Feaster DJ, Gooden L, Schackman BR, Matheson T, Das M, et al. Effect of risk-reduction counseling with rapid HIV testing on risk of acquiring sexually transmitted infections: the AWARE randomized clinical trial. J Am Med Assoc 2013; 310(16): 1701-10.

12. Haukoos J, Thrun M. Eliminating Prevention counseling to improve HIV screening. JAMA 2013; 310(16): 1679-80.

13. Eaton L, Huedo-Medina T, Kalichman S, Pellowski J, Sagherian M, Warren M, etal. Meta-analysis of single-session behavioral interventions to prevent sexually transmitted infections: implications for bundling prevention packages. Am J Public Health 2012; 102(11): e34-44.

14. Fonner V, Denison J, Kennedy C, O’Reilly K, Sweat M. Voluntary counseling and testing (VCT) for changing HIVrelated risk behavior in developing countries. Cochrane Database Syst Rev 2014; (9): CD001224.

15. Irvine C, Egan KJ, ShubberZ, Van Rompay KKA, Beanland RL, Ford N. Efficacy of HIV postexposure prophylaxis: systematic review and meta-analysis of nonhuman primate studies. Clin Infect Dis 2015; 60(Suppl 3): S165-9.

16. Connor E, RS S, Gelber R, Kiselev P, Scott G, O’Sullivan M. Reduction of maternal-infant transmission of Human Immunodeficiency Virus Type 1 vith zidovudine treatment. N Engl J Med 1994; 331: 1173-80.

17. Cardo D, Culver D, Ciesielski C, Srivastava P, Marcus R, Abitebour D, et al. A case-control study of HIV seroconversion in health care workers after percutaneous exposure. N Engl J Med 1997; 337: 1485-90.

18. Ford N, Mayer KH, World Health Organization Postexposure, Barlow L, Bagyinszky F, Calmy A, et al. World Health Organization guidelines on postexposure prophylaxis for HIV: recommendations for a public health approach. Clin Infect Dis 2015; 60(Suppl 3): S161-4.

19. World Health Organization. Guidelines on post-exposure prophylaxis for HIV and the use of co-trimoxazole prophylaxis for HIV-related infections among adults and adolescents and children: recommendations for a public health approach. Geneva, Switzerland: World Health Organization; 2014

20. Ford N, Shubber Z, Calmy A, Irvine C, Rapparini C, Ajose $\mathrm{O}$, et al. Choice of antiretroviral drugs for postexposure prophylaxis for adults and adolescents: a systematic review. Clin Infect Dis 2015; 60(Suppl 3): S170-6.

21. Penazzato M, Dominguez K, Cotton M, Barlow-Mosha L, Ford N. Choice of antiretroviral drugs for postexposure prophylaxis for children: a systematic review. Clin Infect Dis 2015; 60(Suppl 3): S177-81.

22. KaplanJE, Dominguez K, Jobarteh K, Spira TJ. Postexposure prophylaxis against human immunodeficiency virus (HIV): new guidelines from the WHO: a perspective. Clin Infect Dis 2015; 60(Suppl 3): S196-9.

23. Ford N, Venter F, Irvine C, Beanland RL, Shubber Z. Starter packs versus full prescription of antiretroviral drugs for postexposure prophylaxis: a systematic review. Clin Infect Dis 2015; 60(Suppl 3): S182-6.

24. Cohen SE, Liu AY, Bernstein KT, Philip S. Preparing for HIV pre-exposure prophylaxis: lessons learned from post-exposure prophylaxis. Am J Prev Med 2013; 44(1 Suppl 2): S80-5.

25. Schechter M, do Lago RF, Mendelsohn AB, Moreira RI, Moulton LH, Harrison LH. Behavioral impact, acceptability, and HIV incidence among homosexual men with access to postexposure chemoprophylaxis for HIV. J Acquir Immune Defic Syndr 2004; 35(5): 519-25.

26. Baggaley R, Doherty M, Ball A, Ford N, Hirnschall $\mathrm{G}$. The strategic use of antiretrovirals to prevent HIV Infection: a converging agenda. Clin Infect Dis 2015; 60(Suppl 3): S159-60.

27. Jain S, Krakower DS, Mayer KH. The Transition from postexposure prophylaxis to preexposure prophylaxis: an emerging opportunity for biobehavioral HIV prevention. Clin Infect Dis 2015; 60(Suppl 3): S200-4.

28. Siegfried N, Beanland RL, Ford N, Mayer KH. Formulating the future research agenda for postexposure prophylaxis for HIV: methodological challenges and potential approaches. Clin Infect Dis 2015; 60(Suppl 3): S20511. 
29. Baeten JM, Donnell D, Ndase P, Mugo NR, Campbell JD, Wangisi J, et al. Antiretroviral prophylaxis for HIV prevention in heterosexual men and women. N Engl J Med 2012; 367(5): 399-410.

30. Abdool Karim Q, Abdool Karim SS, Frohlich JA, Grobler AC, Baxter C, Mansoor LE, et al. Effectiveness and safety of tenofovir gel, an antiretroviral microbicide, for the prevention of HIV infection in women. Science 2010; 329(5996): 1168-74.

31. Grant R, Lama J, Anderson P, McMachan V, Liu A, Vargas L, et al. Preexposure Chemoprophylaxis for HIV Prevention in Men Who Have Sex with Men. N Engl J Med 2010; 363(27): 2587-99.

32. Peterson L, Taylor D, Roddy R, Belai G, Phillips P, Nanda K, et al. Tenofovir disoproxil fumarate for prevention of HIV infection in women: a phase 2 , double-blind, randomized, placebo-controlled trial. PLoS Clin Trials 2007; 2(5): e27.

33. Thigpen MC, Kebaabetswe PM, Paxton L a, Smith DK, Rose CE, Segolodi TM, et al. Antiretroviral preexposure prophylaxis for heterosexual HIV transmission in Botswana. N Engl J Med 2012; 367(5): 423-34.

34. Van Damme L, Corneli A, Ahmed K, Agot K, Lombaard J, Kapiga S, et al. Preexposure prophylaxis for HIV infection among African women. N Engl J Med 2012; 367(5): 411-22.

35. Choopanya K, Martin M, Suntharasamai P, Sangkum U, Mock PA, Leethochawalit M, et al. Antiretroviral prophylaxis for HIV infection in injecting drug users in Bangkok, Thailand (the Bangkok Tenofovir Study): a randomised, double-blind, placebocontrolled phase 3 trial. Lancet 2013; 381(9883): 2083-90.
36. Jiang J, Yang X, Ye L, Zhou B, Ning C, Huang J, et al. Pre-exposure prophylaxis for the prevention of HIV infection in high risk populations: a meta-analysis of randomized controlled trials. PLoS One 2014; 9(2): e87674.

37. Poynten IM, Jin F, Mao L, Prestage GP, Kippax SC, Kaldor JM, et al. Nonoccupational postexposure prophylaxis, subsequent risk behaviour and HIV incidence in a cohort of Australian homosexual men. AIDS 2009;23(9):1119-26.

38. Cohen MS, Mccauley M, Gamble TR. HIV treatment as prevention and HPTN 052. Curr Opin HIV AIDS 2012; 7: 99-105.

39. Attia S, Egger M, Mu M, Zwahlen M, Low N. Sexual transmission of HIV according to viral load and antiretroviral therapy: systematic review and metaanalysis. AIDS 2009; 23: 1397-404.

40. Cohen MS, Chen YQ, McCauley M, Gamble T, Hosseinipour MC, Kumarasamy N, et al. Prevention of HIV-1 infection with early antiretroviral therapy. N Engl J Med 2011; 365(6): 493-505.

41. Cohen MS, Smith MK, Muessig KE, Hallett TB, Powers KA, Kashuba AD. Antiretroviral treatment of HIV-1 prevents transmission of HIV-1: where do we go from here? Lancet 2013; 382(9903): 1515-24.

42. Anglemyer A, Rutherford G, Baggaley R, Egger M, Siegfried N. Antiretroviral therapy for prevention of HIV transmission in HIV-discordant couples. Cochrane Database Syst Rev 2012; (2): CD009153.

Received on: 04/13/2015

Final version presented on: 05/25/2015

Accepted on: 08/25/2015 